\title{
Harnessing Fisheries Innovation for Transformational Impact in Nepal
}

\author{
Tek Bahadur Gurung
}

\begin{abstract}
In Nepal, per capita fish production lags far below most of the world. To be on par with our neighbors, present fish production would need to be increased at least three- or fourfold. For fish production to have a transformational impact on Nepal's economy, an increase of four- or fivefold would be needed within a decade before the climate change could impact severely the industry. As well, businesses and the government would need to move quickly to produce a more favorable environment for job creation. However, for this transformation to happen pronouncedly, we need to know what additional fisheries technologies would best suit to enhance substantial production under putative climate changes and stimulating socioeconomics for more job and income opportunities. In this paper, we propose several solutions keeping intact aquatic biodiversity. 1) Carp, catfish Pangasius spp, tilapia and rainbow trout would provide the best returns from the marketplace. 2) Recreational fisheries and further cold water aquaculture opportunities need to be improved, 3) Head and tail waters of Pico-, micro-, and mega-hydropower should be prioritized as an area of aquaculture concern for harnessing Nepal's vertical gradient landscape.
\end{abstract}

Key words: Fisheries, innovation, cold water aquaculture, hydropower integration, Nepal

\section{Introduction}

A quaculture innovation holds the potential to transform economics by making better use of customervalue to generate improved products, processes, services and technologies without compromising environmental standards (Costa-Pierce 2008; Kulver and Castle 2008; OECD 2011) and for the benefit of Nepali local communities. As food security continues to pose challenges in Nepal, fish are a necessary complement to staple grains (WFC 2008; IFPRI 2008; NARC 2011). In addition to its value as a supplement to Nepali diets, fish also a desirable source of protein, essential biochemical such as vitamin A, B, omega-3 and other important minerals such as calcium and phosphorus (Gurung 2003; Christopher 2011; WFC 2008).

In Nepal, fish consumption ranks near the bottom when compared with other Asian nations at approximately 2 kilograms per year per capita (DoFD 2013). Much of this is due to low productivity. Fisheries productivity in Nepal has been inhibited by inadequate technological knowledge, education, research, extension systems, low investment, challenging landscapes, and low priority in institutional and capacity building. For example, policy documents such as the Agricultural Perspective Plan (1995-2015) has mentioned fisheries sub-sector as one of dynamic sector but this recommendation could not motivate any serious follow through. As a result the fortune lying at the bottom of Mountain Rivers in terai could not be favorable to enhance fisheries productivity betterment for income and livelihood (Christopher 2011; Gurung 2011). Considering the unique ecological features due to marked altitudinal gradients, fisheries and aquaculture development deserve more attention for transformative impacts. For instance, fish products produced using Himalaya pristine waters could be branded for marketing purposes. Aquaculture is one of the fastest growing food industries in the world (NACA 2010) and in Nepal; the annual growth rate is about $9 \%$, among the fastest growing sectors in agriculture. (Gurung et al. forthcoming). Local communities stand poised to capitalize on this growth as fishing-based livelihoods are common in many rural areas (Christopher 2011). Approximately twelve different ethnic communities, representing about $18 \%$ of total population of the country, are involved directly or indirectly in fisheries (Gurung et al. 2005). In terms of gender, women are also extensively involved in fishing and fishery development (Bhujel et al. 2008; DoFD 2013).

Nepal has diverse agro ecological zone suitable for warm to cold water fisheries. The southern plains of Nepal are one of the most suitable locations for warm water inland aquaculture. Lakes, streams, rivers and reservoirs comprise approximately $5 \%$ of the total area in the country. These inland water resources (including mid and high mountain areas) are the natural habitats of 229 freshwater fish species (Petr 2002; Rajbanshi 2013). These fish could be key sources of food and nutritional security and income to mountain and terai communities

Animal food proteins are inadequate in the hill areas of Nepal. Generally, hill residents, among others suffer from malnutrition, protein deficiency and problems like that of goiter due to iodine deficient diets. People living far from the seashore and high altitude remote villages can suffer from protein-deficient diseases such as goiter, which can be addressed with fish consumption. Freshwater fish including native prawn, turtle, crabs, other invertebrates and aquatic plants, therefore, offer a much-needed source of animal and plant protein, micronutrients, and essential fatty acids.

Nepal has great potential to increase and improve its aquaculture, which could providemulti-Victoriabenefitsfor the country. However, despite the promise of aquaculture, the fishery industry remains a minor subsector (Gurung et al. 2011; Gurung 2008). This paper will elucidate the current weaknesses in fisheries development and point to possible ways forward in this industry. 


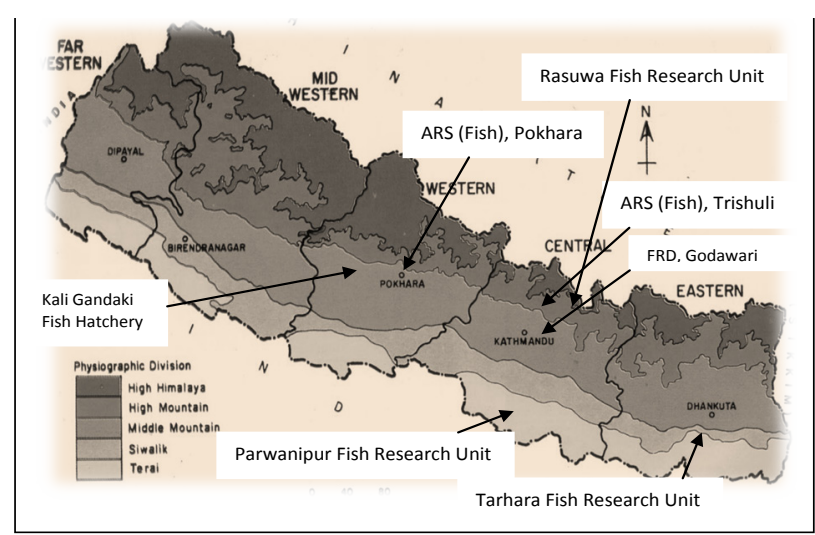

Figure 1: Map showing fisheries research stations in Nepal

\section{Materials and Methods}

The present study is largely based on secondary data collected from various sources. The data on fish production, pond area, and productivity were collected from Directorate of Fisheries Development within the Ministry of Agricultural Development, the Nepal Agricultural Research Council (NARC), Fisheries Research Division, and field visits. The data on investment in fisheries sub-sectors research were obtained from the Nepal Agricultural Research Council as one of the representative samples. The data on fish sales in Kathmandu Valley were obtained from the Kalimati Vegetable Market in Kathmandu, journal articles, and internet research. The fish production data were analyzed using simple linear regression models to show relationships.

\section{Results}

In Nepal, there is an estimated 2,048,353 hectares of water surface area (Table 1). The amount of area available in village ponds is limited; however, the addition of hydropower reservoirs is expected to provide additional water surface area for fisheries and aquaculture in the future.

\begin{tabular}{|c|c|}
\hline Water Resource & Estimated area (ha) \\
\hline \multicolumn{2}{|c|}{ Natural water 401500} \\
\hline Rivers & 395000 \\
\hline Lakes & 5000 \\
\hline Reservoirs & 1500 \\
\hline Village ponds & 6900 \\
\hline \multicolumn{2}{|c|}{ Seasonal water } \\
\hline Marginal swamps & 11100 \\
\hline Irrigated rice fields & 1227353 \\
\hline Irrigation canal length, km & 7900 \\
\hline Total & 2048353 \\
\hline
\end{tabular}

Table 1: Estimated water surface area (ha) in Nepal (DoFD 2013).

There are several institutions directly or indirectly involving in fisheries sector including those of 13 government fisheries development support centers. There are three fish research and experiment centers, and
- Tribhuvan University

- Agriculture and Forestry University

- Kathmandu University,

- Purvanchal University,

- Pokhara University

- Directorate of Fisheries Development (13 Service Centres)

- Nepal Agricultural Research Council Stations:

- $\quad$ Fisheries Research Division, Godawari

- $\quad$ ARS (fish) Pokhara

- $\quad$ ARS (fish) Trishuli)

- $\quad$ Fish Hatchery, Kali Gandaki

- $\quad$ Fisheries Program (RARS, Tarhara)

- $\quad$ Fisheries Program (RARS, Parwanipur)

- $\quad$ Fisheries Program (Nepalgunj)

- $\quad$ Fisheries Program (Doti)

- $\quad$ Cold water fish hatchery, Rasuwa

Table 2: Institutional involved in Fisheries related activities

\begin{tabular}{|l|c|}
\hline Total Fish Production & $54357 \mathrm{mt}$ \\
\hline Capture & $21500 \mathrm{mt}$ \\
\hline Culture Fisheries & $32857 \mathrm{mt}$ \\
\hline Employment & 551,000 \\
\hline Per capita availability & $2.0 \mathrm{~kg}$. \\
\hline GDP contribution & $0.93 \%$ \\
\hline AGDP contribution & $2.61 \%$ \\
\hline
\end{tabular}

Table 3: Fish production (2011/12) in Nepal (DoFD 2013)

two units associated with agricultural research regional stations. In 2014-15, these programs will be joined by the Fisheries Research Programs in Nepalgunj and Doti, and the Cold Water Fish Genetic Resource Center in Rasuwa. They are summarized in table 2.

The contribution of fisheries sector to the GDP is $0.93 \%$ and the industry generates employment for roughly 500,000 people. The total fish production in 201112 was approximately 54 thousand metric tons (Table 3 ).

\begin{tabular}{|c|c|c|c|c|c|c|}
\hline Post & 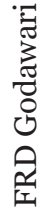 & 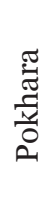 & 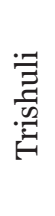 & 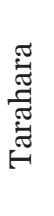 & 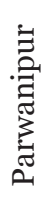 & సేّ \\
\hline $\begin{array}{l}\text { Sen. Sci. } \\
(\mathrm{S}-5)\end{array}$ & 1 & - & - & - & - & 1 \\
\hline $\begin{array}{l}\text { Sen. Sci. } \\
(\mathrm{S}-4)\end{array}$ & - & 2 & $\overline{1}$ & - & - & 3 \\
\hline $\begin{array}{l}\text { Scientist } \\
(\mathrm{S}-1)\end{array}$ & 2 & 1 & - & 1 & - & 4 \\
\hline Tech. Officer & 3 & 6 & 3 & 3 & 3 & 18 \\
\hline Technicians & 5 & 5 & 3 & 2 & 1 & 16 \\
\hline $\begin{array}{l}\text { Adm. \& oth- } \\
\text { ers }\end{array}$ & 16 & 19 & 20 & 5 & 2 & 62 \\
\hline Total & 27 & 33 & 27 & 11 & 6 & 104 \\
\hline
\end{tabular}

Table 4: Existing Human Resource in Fisheries Research (NARC) There has been a regular investment on research to promote fisheries sector under NARC; however compared to other sectors the investment is rather low 


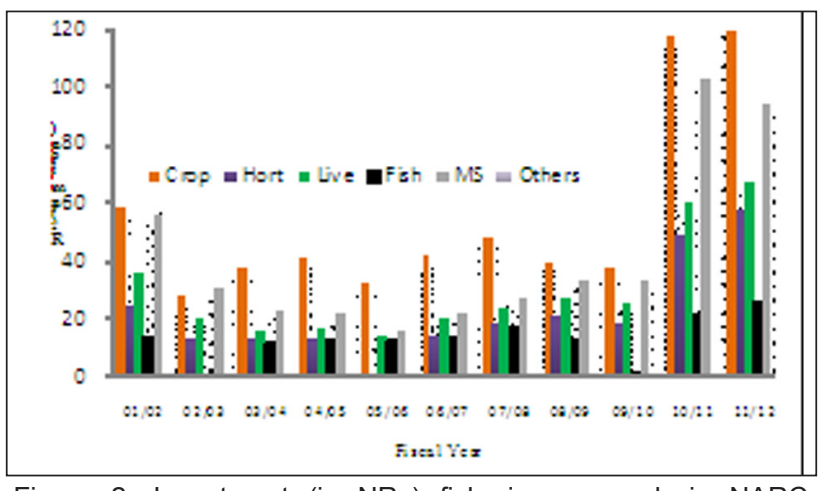

Figure 2: Investment (in NRs) fisheries research in NARC. Symbols used in Fig 5 and 6: Crop=Crop, Hort = horticulture, Live=Livestock, Fish=Fisheries, MS=Mixed Sum

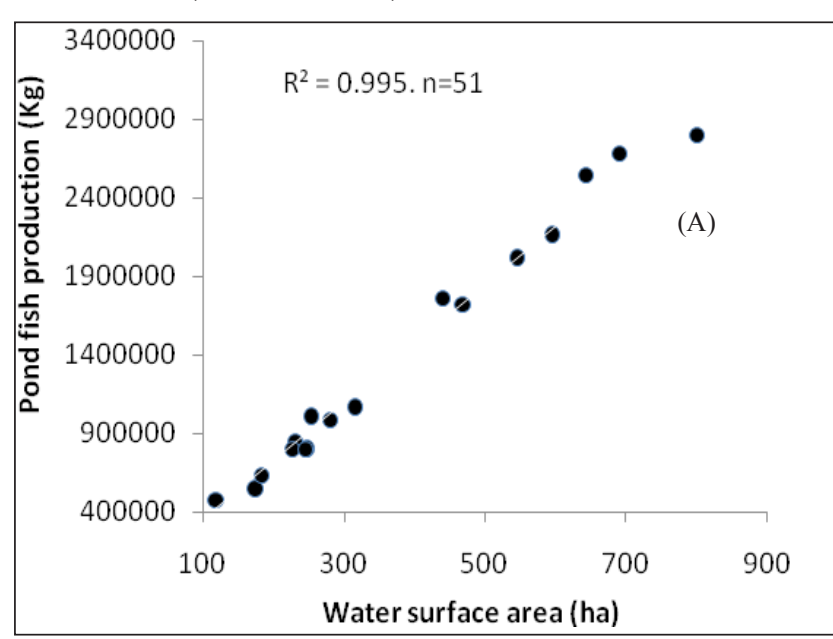

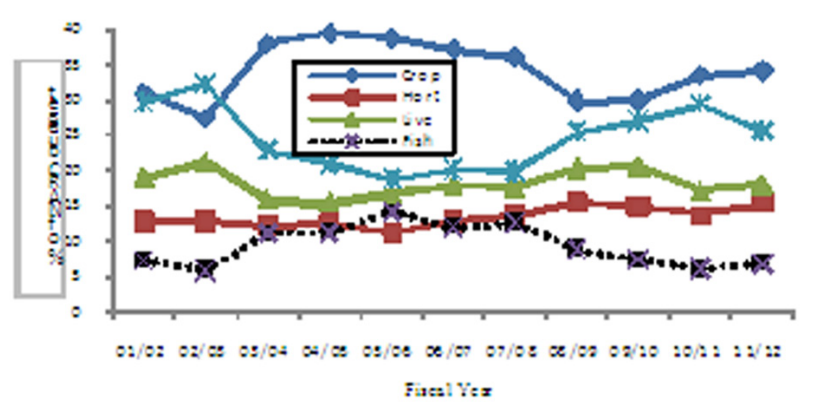

Figure 3: Investment (in \%) on fisheries research in NARC

Figure 4: Relationship between pond fish production (A) and productivity (B) with water surface area.

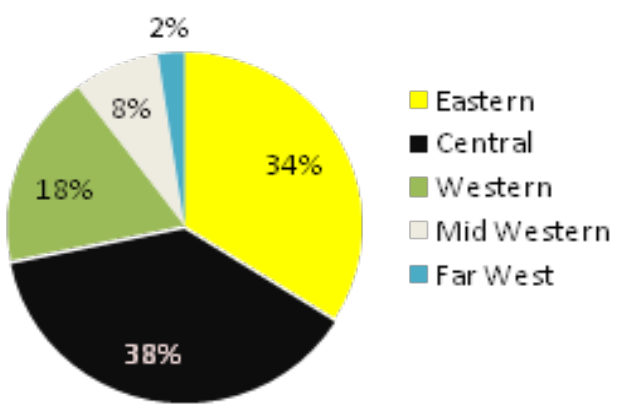

(A) Fish production in terai of different regions

(A) Fish production in terai of different regions

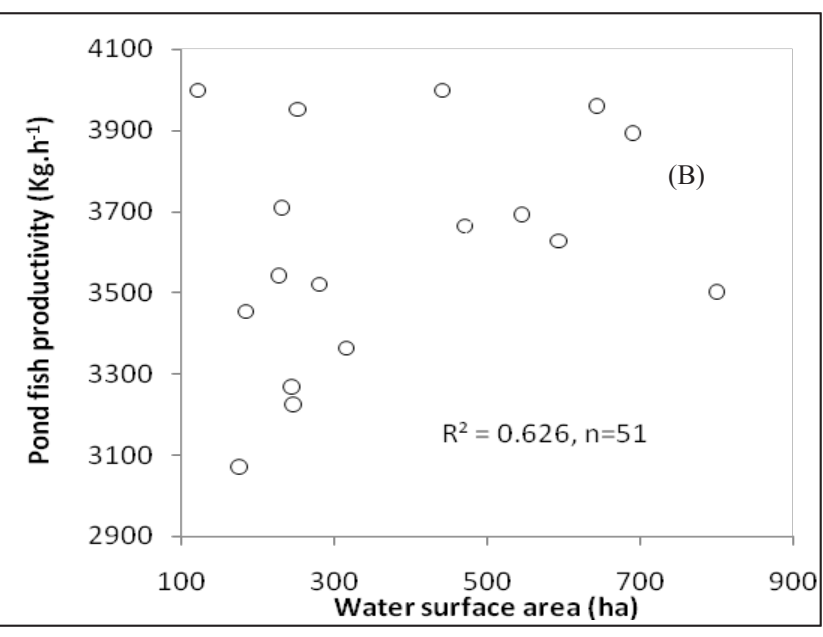

Water surface area (ha)

Figure 5: Status of fish production different ecozone of Nepal

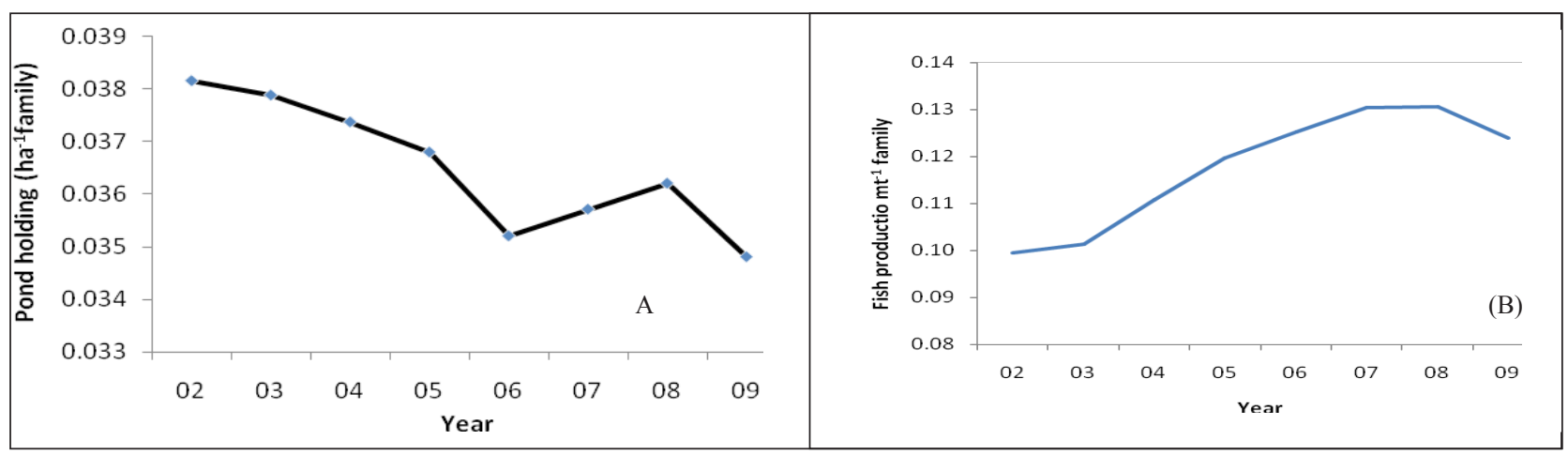

Figure 6: Area of pond holding (ha-1 family (A) and fish production mt-1 family (B) in Nepal 

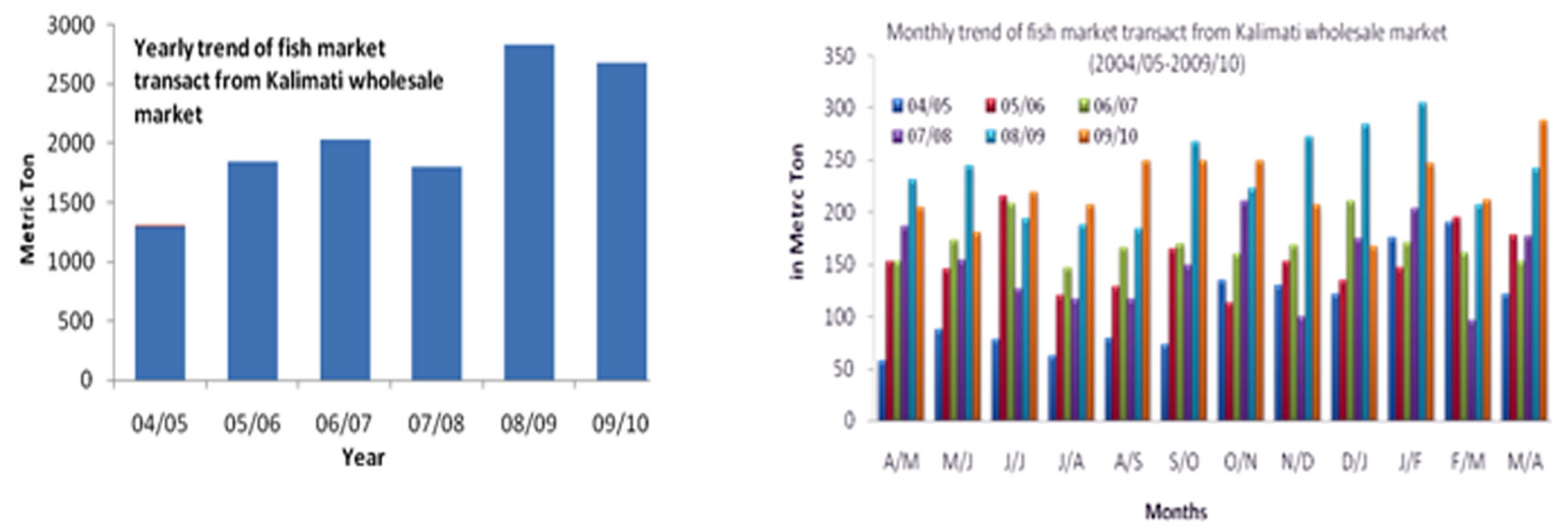

Figure 7: Yearly trend of fish import (A); and monthly trend in Kalimati whole sale market Kathmandu (B).

(figure 2). Figure 3 showed the percentage of investment that fisheries received with those of other sectors funded by NARC.

The comparison of pond fish production against the water surface area showed highly positive correlation $(\mathrm{r} 2=0.995, \mathrm{n}=51)$. When pond fish productivity (production per hector) was compared with the water surface area, it also positively correlated with the water surface area ( $\mathrm{r} 2=0.626, \mathrm{n}=51$ ) (Figure 4 ), suggesting that fish production is more favorable in larger water bodies. Figure 5 showed that $99 \%$ of fish production from pond aquaculture originates in the terai.

Within the terai, fish production varied by region: $38 \%$ in the central, compared to $34 \&, 18 \%$ and $8 \%$ in the eastern, western and mid-western regions, respectively (figure 8).

Per family pond holding and fish production were also evaluated (figure 6a). The analysis revealed that the area coverage of pond holding per family has been declined steadily since 2002. The family pond holding in 2002 was nearly 0.04 ha, but in 2010 that has declined to o.035 ha. However, when fish production per family was calculated, production rose steadily from 2002-2007, and then leveled off in 2009 (figure 6b).

\section{Fresh Fish Import}

The yearly trend of fish import data collected from Kalimati wholesale market for the years 2004-2010 revealed that fresh fish import was tended to increase from $1,800 \mathrm{mt}$ in year 2004/o5 to $2,800 \mathrm{mt}$ in year 2008/o9 (Figure 7a).

Figure $7 \mathrm{~b}$ breaks down the amounts of fresh fish month. Kalimati reported more fish during the winter, approximately $300 \mathrm{mt}$ per month. The low season for fresh fish appears to be March and April when the market received only $52 \mathrm{mt}$.

\section{Discussion}

The fisheries sector in Nepal is currently small but has great potential for growth. Cold water fishery development in the mountains can be a challenge, but recent technological development of cold water aquaculture has opened immense possibilities for the hill and mountain regions (Gurung 2008; Gurung et al. in press). Currently, carp is the most commonly cultivated fish in aquaculture, rainbow trout is coming up successfully, more species can potentially flourished (box 1).

\begin{tabular}{|c|c|}
\hline \multicolumn{2}{|r|}{ Box 1: Main fish groups cultivated in Nepal } \\
\hline $\begin{array}{l}2 . \\
3 . \\
4 .\end{array}$ & $\begin{array}{l}\text { Carp } \\
\text { Rohu (Labeo rohita) } \\
\text { Naini (Cirrhinus mrigala) } \\
\text { Bhakur (Catla catla) } \\
\text { - Indigenous (Non-commercial scale) } \\
\text { Sahar (Tor putitora) } \\
\text { Asala (Shizothorax spp) } \\
\text { Katle (Neolissochilus hexagonolepis) } \\
\text { - Introduced (Commercial scale) } \\
\text { Common carp (Cyprinus carpio) } \\
\text { Bighead carp (Aristichthys nobilis) } \\
\text { Silver carp (Hypophthalmicthys molitrix) Grass carp } \\
\text { (Ctenopharyngodon idella) } \\
\text { Rainbow trout(Oncorhynchus mykiss) } \\
\text { GIFT Tilapia (Tilapia niloticus) } \\
\text { Catfish (Commercial scale) } \\
\text { a) Exotic (Clarias gairepinus), } \\
\text { b) Pangas (Pangasius hypophthalmus) } \\
\text { Catfish (Non-Commercial scale) } \\
\text { c) Indigenous Mungri (Clarias batrachus) } \\
\text { Ornamental fishes } \\
\text { Other indigenous fishes }\end{array}$ \\
\hline
\end{tabular}

The greatest promise for aquaculture in Nepal is the tremendous water availability, which covers more than $5 \%$ of the total land area in the country. Nepal has more than 6,00o rivers, which may also be used in aquaculture production. Lakes, reservoirs and village ponds comprise $3.39 \%$ of the water surface areas within rivers. These statistics suggest that there are ample opportunities of fish production, requiring only nominal river water to start.

Interest in aquaculture is growing in Nepal at present, 55 districts out of 75 districts have aquaculture production programs compared with only 30 districts a decade ago. A technological package developed on cold water fish rainbow trout (Gurung 2008) has been helpful to expand fish culture expansion in hill and mountain districts. The adoption of rainbow trout cultivation 
in hills and mountains has been rapid (Gurung et al. forthcoming). To support and enhance cold water aquaculture productivity, more innovative technologies and interventions are expected. However, as noted in table 4, there are limited scientific human resources available for fisheries research. Transformational impact of fisheries and aquaculture development would require a new commitment of human talent.

NARC Vision, issued in 2011, sees fisheries as one of the important sectors in agriculture. However, the budget allocations to this sector do not support that claim. We found that from 2001/02 to 2011/12, annual allocations were meager, ranging from $\$ 2.75$ million in 2004 to just $\$ 1.4$ million in 2008. In each year, NARC allocated roughly $9 \%$ of its budget to fisheries, while other research took the largest share. In our estimation, the budget for aquaculture development would need to double in order for Nepal to compete with other countries in warm water carp and cold water trout (figure $7 \mathrm{a} \& \mathrm{~b}$ ).

The pond fish production that we discussed in the previous section (figure 7a) showed high degree of correlation $(\mathrm{r} 2=0.99, \mathrm{n}=51)$ in relation to water surface area. The correlation reflected that the fish production should be increased more with additional technological improvement and innovation. The pond fish productivity also showed positive and significant correlation ( $\mathrm{r} 2=0.626, \mathrm{n}=51$ ) with pond water surface area, although, the magnitude of the strength was relatively weak. This can likely be explained by the diverse agroecological arrangement at higher altitudes. Pond fish farming expansion has also not been uniform in southern plain districts (figure $8 \mathrm{a} \& \mathrm{~b}$ ). Regionally speaking, the far western region has lagged behind in fish production, which represents a true area for growth as the far west has a high number of wetlands, lakes and the residents desiring fish for social occasions. Along with the far west, the mid-western and western regions should be prioritized for aquaculture because these regions are located more close to market headquarters for accessible marketing of theirs products.

Decreasing pond holding areas per family (figure 9 a \& b) may indicate family fragmentation due to migration in rural Nepal. The fish production per family, however, has demonstrated an increase, which may be due to the increasing intensification of pond farming practices. This rise in production may also indicate increasing technological skill of farmers and the use of inputs for better production.

The demand for fresh fish is increasing in Nepal as the country becomes more aware of health and nutrition. Still, the amount of fish produced in Nepal lags behind domestic demand and well behind the global average of $16 \mathrm{~kg}$ per capita. As a result, much fish is imported from India at a value of 1.5 billion Nepali rupees per year (Gurung 2012). Fish traders who import to Nepal report that domestic production could increase tenfold without overtaking demand. To check this claim, we analyzed the monthly fish import (figure $10 \mathrm{a} \& \mathrm{~b}$ ) on the assumption that the fresh fish consumption increases about 3-4 times more in winter (Dec-Feb) due to mass belief that consumption of fish is comparatively hygienically safe in winter than summer; and biggest festivals (OctNovember) months. Contrary to the assumption, the monthly fish import pattern did not show this trend substantially, except slightly higher fish import in winter months (Fig 10 B), as have been hypothesized. The fish import in festival months, October and November, could not also support the assumption. This analysis showed the present values obtained from the wholesale market should be far below real values implying that the claim of 10 folds higher market demand of fish might close to the fact.

Among the various institutions where fisheries and aquaculture have been undertaken as research components, NARC seems to have the most extended network of research activity focusing on technology generation compared to others. Box 2 summarizes some of NARC fish production-related work.

\section{Box 2: Research accomplishment under Nepal Agri- cultural Research Council in Nepal}

- Mass scale seed production of high valued and endangered indigenous fish Tor putitora

- Mass scale fish larval methodological development of Tor putitora

- Breeding success with hybrid production of catfish (Clarias batrachus)

- Increased hatchability of rainbow trout (Oncorhynchus mykiss)

- Increased survivability of trout larvae

- Initiation for producing all male population of Tilapia

- Breeding success of ornamental fishes such as: - Japanese Koi carp, Guppy, Gold fish, Molly, Sword tail

- Breeding and nursing technologies of several native fishes (Jalkapoor, Gardi)

- Methods for conservation and restoration of lakes using carp

- Breeding success with hybrid production of catfish (Clarias spp and others)

For harnessing the transformational impact of fisheries, it would be essential to enhance capabilities in academia as well as government agencies. Together, these groups would need to devise a vision that accounts for Nepal's unique vertical gradient agro-ecology of Nepal.

Traditionally, rivers are dammed or regulated to harness Pico-, micro-, or mega-hydro energy after which tailrace water is released back to river course (figure 11). It would be more economical and environmentally rational to use head or tail water for aquaculture and agriculture integration because the expense of the infrastructure for hydropower, irrigation canals, and aquaculture ponds could lower costs through efficiencies. This type of integration would be beneficial in mountainous agroecological countries like Nepal (De Silva 2012). Since the aquaculture borrows the water temporarily without any consumption, the water discharged after aquaculture use can again be used for irrigation or even for hydropower. 
The purpose of hydropower-aquaculture-agriculture integration would be harnessing the advantages of
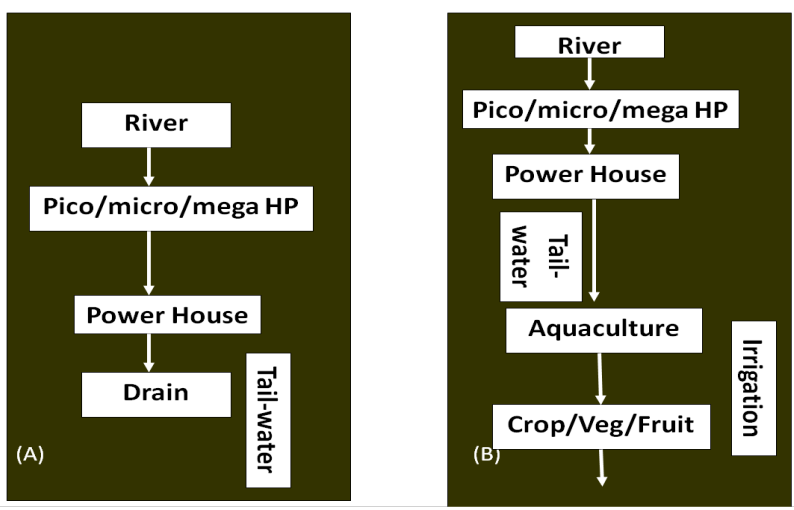

Scheme of traditional (A) and modern views for agriculturehydropower integration (B) PN

Figure 8: Schematic view of traditional (A) and modern view (B) of aquaculture and agriculture hydropower integration suitable to mountainous countries

altitudinal natural gradient of mountainous landscape. With the technological innovation (Gurung 2010) of highly commercial rainbow trout aquaculture, now fish production has been demonstrated at least in 23 hill and mountainous districts of Nepal with prospects to expand in all hilly areas of Nepal including TransHimalayan countries (Gurung et al, in press). This successful innovation links the part of the story to the fact that aquaculture is one of the fastest food industries of the world, and social transformation would prevail especially among small holder led agriculture societies.

\section{Conclusion}

Aquaculture practices are rise in Nepal. To enhance more production besides the terai ponds; lakes, mountainous rivers sides, hydropower head and tail waters should be planned for aquaculture purposes. These steps would indeed be in line with country's geographical set up well renounced for vertical and steeply gradients. The approach can also fulfill effectively the scantly available land for general agriculture and livestock activities for food and nutrient security in the country. Since the cold water along with warm water fisheries technology have been shown its positive attributes, therefore further scaling up of the technologies with additional human talent and innovation would be the opportunity in this sector for transformational impact in Nepal economics.

\section{Acknowledgement}

My sincere appreciation to Dr. Pipoppinyo Somsak, Mr. Weimin Miao of Food and Agriculture Organization (FAO); Professors Jotaro Urabe, Tohoku University, Japan; Masami Nakanishi, John Richard Jones. Thanks are also extended to Japan International Cooperation Agency (JICA), the World Bank, Asian Development Bank and Dr. D. B. Gurung, Executive Director of NARC for promoting fisheries and aquaculture in Nepal.
Tek Bahadur Gurung, PhD, is Principal Scientist (Fisheries) and Director of Livestock and Fisheries Research in Nepal Agricultural Research Council (NARC). Dr. Gurung graduated from Gorakhpur University, India, and Kyoto University, Japan, and pursued post doctorate studies as Fulbright Scholar at the University of Missori/Columbia, USA. He is currently working as a Principal Scientist engaged in supervision and guidance of livestock and fisheries research in Nepal. He has devoted his career to fi sheries and aquaculture research, especially on developing cold water aquaculture technologies and carp fish breeding in inner Himalayan foothills. Dr. Gurung has published over 50 papers in national and international peer reviewed scientific journals.

Corresponding address: tek_fisheries@hotmail.com

\section{References}

ADS, 2012, Preparation of the Agricultural Development Strategy (ADS), Draft Vision Report Prepared for Government of Nepal With the support of ADB, IFAD, EU, FAO, SDC, JICA, WFP, USAID, DANIDA, World Bank, and DFID, p 61.

APP, 1995, Agriculture Prospective Plan, APROSC, Kathmandu \& John Mellor Associates Inc, Washington DC, June 1995.

Bhujel R. C, M. K. Shrestha, J. Pant, S. Buranrom, 2008,'Ethnic women in aquaculture in Nepal'. Development, 51. 259-264.doi:10.1057/dev.2008. 11

Christopher A. 2011,'Re inventing aquaculture for the economic and cultural stability of the poor in the mid hills of Nepal, a research review'. Ecological Aquaculture Studies \& Reviews, University of Rhode Island, Kingston, R.I. www.ecologicalaquaculture. org/Andrikos

Costa-Pierce B. A., 2008, Epilogue: Aquaculture, Innovation and Social Transformation K. Culver and D. Castle, Editors. Aquaculture, Innovation and Social Transformation. Springer, New York.

Culver K. C and D. Castle (eds), 2008, Aquaculture, Innovation and Social Transformation, Springer, p 345.

De Silva, S. S., 2012, Aquaculture : a newly emergent food production sector-and perspectives of its impacts on biodiversity and conservation, Biodiversity and conservation, vol. 21, no. 12, pp. 3187-3220.

DoFD, 2013, Country profile: Fisheries, published by Fisheries Development Directorate, Balajoo, Nepal.

Gómez-Pinilla F, 2008, Brain foods: the effects of nutrients on brain function. Nat Rev Neurosci.9 (7): 568-578. doi: 10.1038/nrn2421.

Gurung T. B, 2003, Fisheries and aquaculture in Nepal. Aquaculture Asia, Network of Aquaculture Center in Asia (NACA).

Gurung T. B, 2005, Responsible introduction of alien fish and biodiversity in southern Nepal. Aquaculture Asia, Volume X No. 2 April-June 2005, p13-15.

Gurung T. B, 2008,Proceedings of the workshop on scaling-up of Rainbow trout (Oncorhynchus mykiss) 
farming strategies in Nepal (Ed), Published by: Fisheries Research Division, Godawari, Lalitpur of NARC, pp 158.

Gurung T. B, 2010, Rainbow trout: A precious souvenir from Japan published in MILAN magazine, a JICA Alumni Association 37 Annual Issue, 2010, p 15-17. https://www.researchgate. net/publication/236340926_Rainbow_trout_. precious_souvenir_from_Japan?ev=prf_pub.

Gurung T. B. Wagle S. K, Bista J. D, Dhakal R. P, Joshi P. L, Batajoo R, Adhikari P and Rai A. K, 2005, Participatory fisheries management for livelihood improvement of fishers in Phewa Lake, Pokhara, Nepal, Himalayan Journal of Sciences 3(5): 47-52.

Gurung T. B, R. M Mulmi, K. KC, G. Wagle, G B Pradhan, K. Upadhayaya, and Rai A K, 2011, The success on adoption of cage fish culture as an alternative livelihood option for communities displaced by reservoir impoundment in Kulekhani, Nepal. 2009. In: S. S. De Silva; F. B. Davy (eds.), Success Stories in Asian Aquaculture Published by the Network of Aquaculture Centers in Asia-Pacific, p 85-99, Springer.

Gurung T. B, 2011, Prospects of cold water fisheries in high altitude wetlands, paper published in Proceedings of the 8th National Workshop on Livestock and Fisheries Research, edited by $\mathrm{T}$ B Gurung, P K Pokharel, C R Upreti, B R Joshi, S M Pradhan and S K Wagle, NARC, 336.

Gurung T. B, 2012, Integrated Aquaculture within Agriculture Irrigation for Food Security and Adaptation to Climate Change. 2012. HYDRO NEPAL Journal, SPECIAL ISSUE, 73-77.

Gurung T. B, S. K. Wagle, A. P. Nepal, G. P. Lamsal (in press), Emerging trends of cold water fish rainbow trout (Oncorhynchusmykiss) farming in Nepal Himalaya, SAARC Agriculture Journal.
OECD, 2011, 'Fostering Innovation to Address Social Challenges', workshop proceedings, http://www. oecd.org/sti/inno/47861327.pdf.

NARC Vision, 2010, NARC's Strategic Vision for Agricultural Research (2011-2030), Meeting Nepal's Food and Nutrition Security Goals through Agricultural Science \&

Technology, Nepal Agricultural Research Council, p 56.

Petr T, 2002, Mountain Fisheries in Developing Countries, FAO Consultant, FAO Rome Toowoomba, Queensland Australia, p 55.

Rajbanshi K G, 2013, 'Fish and Fisheries of Central Himalaya, Nepal'. Published by Nepal Fisheries Society, Kathmandu, Nepal.

Subasinghe R P, D Curry, Sharon E. Mc Gladdery and D Bartley, 2013, Recent Technological Innovations in Aquaculture Senior Fishery Resources Officer (Aquaculture) FAO Fisheries Department Rome, Italy.

Swar D. B. 2002, The status of cold water fish and fisheries in Nepal and prospects of their utilization for poverty reduction. In: Cold water fisheries in the trans-Himalayan countries. Petr T and Swar D. B (eds). FAO Fisheries Technical Papers 431. Published by FAO.p. 376.

IFPRI, 2008, Advancing Agriculture in Developing Countries through Knowledge

and Innovation, Synopsis of an International Conference Kwadwo Asenso-Okyere, Kristin Davis, and Dejene Aredo, International Food Policy Research Institute Washington, D.C.

WFC, 2006, Aquaculture, fisheries, poverty and food security in Africa, World Fish Center, Penang Malaysia $\mathrm{p} 12$.

WFC, 2008, World Fish Center: Using Fisheries and Aquaculture to Reduce Poverty and Hunger, p 12. www.worldfishcenter.org.

\section{CALENDER OF EVENT-HYDROPOWER}

04-05 September, 2014: Small Hydro Workshop. Location: Five Pine Lodge Sisters, Oregon. URL: http://www.nwhydro.org/events_committees/low_ impact_hydro_workshop.htm

29-30 October, 2014: Fall Workshop \& Tour. Location: the Davenport Hotel Spokane, Washington. URL: http://www.nwhydro.org/events_committees/ regional_meeting.htm

17-19 February, 2015: Annual Conference. Location: Portland Marriot Downtown Waterfront Hotel Portland, Oregon. URL: http://www.nwhydro.org/ events_committees/AnnnualConference.htm

07-08 May, 2015: Technical \& Operations Seminar. Location: Hood River Inn, Hood River, Oregon. URL: http://www.nwhydro. org/events_committees/tech_operations_ conference.htm

21 - 26 September, 2014: the IWA World Water
Congress and Exhibition. Contact: International Water Association, Koningin Julianaplein 2,2595 AA Den Haag, the Netherlands. Location: Lisbon, Portugal, Email: 2014lisbon@iwahq.org URL: www. iwa2014lisbon.org

22-26 September, 2014: the 27th IAHR Symposium: Hydraulic Machinery and Systems. Contact: IS Event Solutions, 607 Notre-Dames, St- Lambert, Quebec, J4P 2K8, Canada. Location: Montereal, Canada. Email: carole@iseventsolutions.com or sabina@ iseventsolutions.com URL: www.iahrmontreal2014. org

6-8 October, 2014: International Association for Small Hydro Forthcoming Events. Location: New Delhi, India. URL: www.iash.info/eventiash.htm

19-21 October, 2014: Power Gen Middle East. Location: Abu Dhabi, UAE. URL: http//www.power-genmiddleeast.com 